\title{
Tradition critical study of 1 Chronicles 21
}

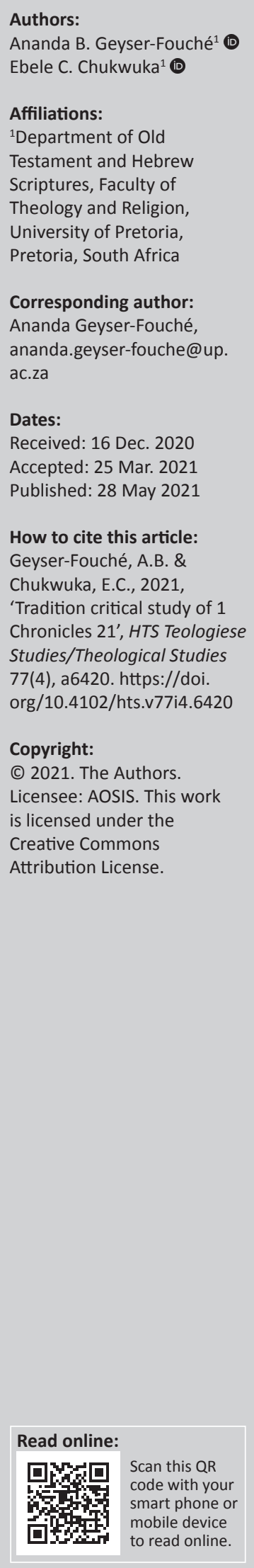

The purpose of this article was to highlight the importance of tradition criticism as a significant aspect of the exegetical study of any Old Testament text. Different traditions existed in ancient Israel, and the Chronicler emphasised or underemphasised some of these in 1 Chronicles 21. The above-mentioned practices highlight the theology and ideology that the Chronicler wanted to promote. The Chronicler emphasised certain traditions and underemphasised others in such a way that both the theology and ideology of the Jerusalem Temple stood out. The Jerusalem Temple represented the Chronicler's theology and his image of God - which was that Yahweh is only to be worshipped in the Jerusalem Temple, that he has chosen the site as the place for worship and that he is dwelling there. The findings of this research caution against reading and understanding a text outside its unique historical context. This is because the Old Testament does not have a central theme or one theology.

Contribution: This article contributes to the focus in HTS Teologiese Studies/Theological Studies with regard to the notion 'historical thought', covering textual and hermeneutical studies as expressed in the Hebrew Scriptures. The hermeneutical method of tradition criticism is applied in this article, forming part of the scope of this journal to embrace critical textual readings.

Keywords: Chronicles; Satan; tradition criticism; Chronicler; 1 Chronicles 21.

\section{Introduction ${ }^{1}$}

This article aims to highlight the importance of tradition critical study as a very significant aspect of the exegetical study of any Old Testament text, with specific focus on 1 Chronicles 21. 1 Chronicles 21 has been a much-debated text, primarily because of the presence of Satan or satan and the fact that this text seems to be an amended version of 2 Samuel 24. In 1 Chronicles 21, the Chronicler redacted the text of 2 Samuel 24. He utilised his sources selectively to retell the story with his own emphasis. This article will primarily focus on the traditions that are highlighted in 1 Chronicles 21 with an overview of the traditions in the book of Chronicles, read against theology and ideology of the book.

\section{The different traditions that existed in ancient Israel}

Glassie (1995:395) defined tradition as the 'creation of the future out of the past', and its understanding begins with the refining of tradition in conjunction with history and culture. Traditions die at some point, and another tradition replaces them. Continuing change in tradition from one generation to another is what historians describe as the moment in which a superior replaces an inferior. Historians need tradition, as it enables them to face the massive fact of continuity in any progressive society (Glassie 1995:396).

Tradition can be linked to culture. Together, they can be understood to be created by human beings going through change. Also, both are created by individuals out of experience, and the reason for their actions entails change (Glassie 1995:398-399).

The change in tradition cautions against reading and understanding of any text outside its unique historical context. The change in tradition supports the notion that there is not one central theme or one theology in the Old Testament. Tradition critical study, therefore, becomes an essential tool for an exegetical study of any portion of the Old Testament, and one should always consider the different traditions the authors engaged with, to understand the theology and ideology behind the text.

1.In this article, "Chronicler' will only refer to the author(s) and/or redactor(s) of $1 \& 2$ Chronicles. It can be noted that traditionally it was believed that Ezra and Nehemiah can also be included into the work done by this author (cf. Smith 2010:4). It is, however, generally accepted that, through linguistic and theological research, this is not the case (cf. Japhet 1968; Smith 2010:4). 
Tradition critical study creates the cognisance that some Old Testament texts can be polemic against the cultural relativism of the older traditions or other texts (cf. Brueggemann 2013:3-5; Geyser-Fouche 2017:5). In the Old Testament texts, there is always a certain amount of dialectical tension (cf. Brueggemann 2008:213-215). Hence, in reading the Old Testament texts, it is important to keep in mind that one should be aware that texts are written for their specific contexts and that certain groups used texts to empower themselves. According to Geyser-Fouche (2016:7), by making use of exclusive language, certain groups can empower themselves whilst excluding other groups. Thus, the Old Testament texts are relational (cf. Breytenbach 1995:708-709; Geyser-Fouche 2017:3). The core of all Old Testament texts is centred around the relationship between Yahweh and the nation. The fact that Old Testament texts deal with God in relation to human beings includes a human aspect, and it is precisely this that makes people think and decide differently in and about the texts and the interpretation thereof at different times and in different contexts. It, therefore, remains essential for the texts to be read within context, as well as interpreted, and then translated into the current context.

Therefore, in the application of the varying principles garnered from the study of a text, we should not focus on the culture or the controversy, rather on the relationship between God and man.

According to Boda and McConville (2012:99), so many traditions were expressed in the Old Testament that are part of Israel's history and theological and/or ideological framework. They state that the concept of covenant was clearly outlined in the Pentateuch. They thought covenant as a simple pact or treaty between two or more people. However, they stress that God's covenant with his people is broader in focus and contains promises that God makes on behalf of his people (Boda \& McConville 2012:99).

The covenant tradition in Boda and McConville's (2012:99) view can be subdivided into universal, ancestral and national. The universal refers to the covenant that God established with creation after the universal flood in Genesis 6-9. The ancestral covenants refer to the covenants that God made with Abraham. The covenants were alluded to by the prophets, who speak directly about specific covenants. God's servants and prophets speak mostly of the Abrahamic, Mosaic, Davidic and new covenants'.

\section{The Abrahamic covenant}

Boda and McConville (2012:99) explicated that in the Abrahamic covenant, God promised 'Abraham a great name, a great nation and great land'. These promises, in their view, were partly fulfilled by the time of Moses and Joshua. However, they added that Abraham was not only going to receive a divine blessing but also would be a blessing to others (Gn 12:3). The Abrahamic covenant was used by the prophets to either encourage or exhort his people, who were Abraham's offspring.
The concept of the covenant comes to the forefront using the covenant formula (Boda \& McConville 2012:100). For example, in Genesis 17:7-8, God affirms to Abraham twice that he will establish his covenant between him and Abraham, to be God to him and his offspring after him. The significance of this covenant is that Abraham, in his lifetime, rejected false gods in favour of the true God. This covenant is believed to be extended to all Jews (Abraham's offspring) and was the start of a relationship between God and the Jews.

According to Genesis 17:10-14, as a token of the covenant, God required Abraham to circumcise every male child amongst him. This applied to every male child, whether born in his household or bought with his money from a foreigner. Any uncircumcised male amongst Abraham and his descendants who was not circumcised in the flesh will be cut off from his people because he has broken God's covenant. Circumcision, therefore, was commonly observed as part of the Abrahamic covenant tradition.

\section{The Mosaic covenant}

In Exodus 6:2-6, before the establishment of the Mosaic covenant, God reminds his people (Jewish people) of the covenant he made with Abraham. In Exodus 6:7, the covenant formula is repeated, I will take you to be my people, and I will be your God. Re-emphasizing this formula demonstrates that what God desired is a relationship with the people. However, Boda and McConville (2012:100) understood the promise in this passage to be in the context of the land promise, which will be a recurring theme in other subsequent covenants. The Mosaic covenant was established at Sinai, and thus, it can sometimes be referred to as the Sinai tradition and is the most prominent of the covenant with Israel.

The Mosaic covenant was a continuation of the Abrahamic covenant. There are similarities between the two covenants. Both have the appearance of the covenant formula, the land promise is prominent in both and God's promise to Abraham is the main reason for his intervention over Israel in Egypt. The most important teaching of the Mosaic covenant is the Ten Commandments. The prominent tradition amongst the prophetic books of the Old Testament was the Mosaic covenant, and evidently, the prophets always referred back to the Ten Commandments to address the people, over keeping and breaking of the covenant (Boda \& McConville 2012:100).

\section{The Davidic covenant}

Another tradition expressed in the Old Testament is the Zion tradition, which is mostly related to the Davidic Monarchy (Boda \& McConville 2012:907). Three elements emerge in any discussion of Zion tradition, that is, the city, Yahwistic religion and monarchy. The discussion of what is known as the Zion tradition expresses the relationship between these three elements. According to Boda and McConville (2012:103), the Davidic covenant comes with promises from God with David, which includes those that will be fulfilled in David's 
lifetime (2 Sm 7:9-11a) and those that will find realisation after David's death (2 Sm 7:11b-16).

Grisanti (1999:237) noted that the promises that were realised during David's lifetime are, firstly, a great name. In this first promise, the Lord promises to make David's name great in 2 Samuel 7:9, like the promise he made to Abraham in Genesis 12:2. Although David accomplished so much as a king that caused his reputation to grow, Grisanti emphasised that it was God who was the driving force in making David's name great. Grisanti asserted that God is the one who orchestrated David's transition from being a common shepherd to serving as the king over all Israel. Secondly, Grisanti's view is that during David's reign, Israel controlled land that approached the ideal boundaries of the promised land, which was initially stated within God's covenant with Abraham.

Similarly, Grisanti (1999:238) observed that the promises that was realised after David's death is, first, a house. Grisanti's view is that moving the ark of God to the city of Jerusalem after David's death represents God's choice of Jerusalem as the future site for the temple. Grisanti added that Israel is reminded of God's kingship over it by the presence of God, which rests on the ark of the covenant. According to Grisanti, God permits the building of a house of worship by Solomon, David's son. In so doing, God also attends to the eternal house of David. In Grisanti's opinion, the house in the context here refers to David's dynasty rather than his immediate family or even his lineage. The house here suggests a duration that exceeds most family lineages.

Grisanti (1999:238) wrote that the second promise that was realised after David's death is a seed, which in his opinion refers to Solomon, to all the royal descendants of David and ultimately to the Messiah, Jesus Christ. Grisanti concluded that God guarantees that Davidic descendant would always be available to sit on the royal throne.

\section{Other traditions and covenants}

There appears to be a continuity that connects the Abrahamic, Mosaic and Davidic covenants. However, the ancient traditions in Israel are not limited to these three covenants. Many other traditions existed in ancient Israel. They are the exodus tradition, the Northern traditions, the temple tradition, the Southern tradition, the patriarchal tradition, the Sinai tradition, the Zion tradition and the promised land tradition, to name but a few. Some of them will be discussed further in the succeeding sections. The different traditions that existed in ancient Israel influenced the authors of the Old Testament literature. The tradition critical study not only helps to uncover the earlier stages of the book of Chronicles' text history and development but also reveals how the forms of laws, creeds, songs, genealogies, poems, stories and other types of writing were passed on from one generation to the next orally. These transmissions of information usually happen as a way of preserving history, before the book's final form (cf. Holladay \& Hayes 1982:85).

\section{Tradition critical reading of 1 Chronicles 21}

Based on the information garnered under the theoretical framework above, tradition critical reading of the book of Chronicles can, therefore, be understood in this study as a method of critical examination of the concepts used to trace the developmental stages of the book of Chronicles from its historical advent to its literary presentation in the Hebrew Bible (Holladay \& Hayes 1982:85).

Boda and McConville's (2012:907) explanation about the tradition history seems to relate the Zion tradition mostly to the text of 1 Chronicles 21. The text focuses mainly on David, whose monarchy is related to the Zion tradition. The tradition expresses the relationship between the three elements of the city, Yahwistic religion and the monarchy.

Geyser-Fouche (2016:5) observed that the Chronicler portrayed David as the ideal King, not only in the genealogies but also in the narrative part about the Kings, as the patron of the Temple. However, the only adverse mention linked to David was in the census he undertook in 1 Chronicles 21. Nevertheless, Geyser-Fouché stated that the motive is the result, which is 'the indication of the site chosen for building the Temple'.

There is an enormous amount of evidence, and this agrees with the view of many scholars ${ }^{2}$ that the Chronicler utilised many sources, both biblical and non-biblical. He relied heavily on the books of Samuel, Kings and the Pentateuch. Based on the preceding information and information garnered under the theoretical framework, it is evident that the Chronicler borrowed from the different traditions and omitted some traditions that existed along with Israel's history.

The Chronicler did not mention the Mosaic covenant, as Moses 'was associated with Shechem (Dt 27) and a symbol of the Northern Kingdom'. The Abrahamic covenant is not mentioned either because he is associated with Mount Gerizim, which is perceived as a Samaritan location. The traditions that describe Yahweh as the Lord of Abraham, Isaac and Jacob are silenced in 1 Chronicles 21, as well as in the whole book of Chronicles (Geyser-Fouche 2016:6).

The author of Chronicles used exclusive language to emphasise and underemphasise, as well as silence, voices to depict one specific ideology, which is the legitimisation of the Yahweh worship in the Temple of Jerusalem (cf. GeyserFouche 2016:6).

2.Knoppers (2004:743) is of the view that the Chronicler could be characterised as a reforming historian. He asserts that 1 Chronicles $21: 1-27$ is largely taken from the Chronicler's Vorlage of 2 Samuel 24:1-25, while $1 \mathrm{Chr} 21: 28-22: 1$ is unique to Chronicles'. According to Nahkola (2001:13-14), the Chronicler's redaction of the narratives of David and Solomon were deliberate and transparent marring of the original narrative as it is found in Samuel. He retouched the old picture, to of the original narrative as it is found in Samuel. He retouched the old picture, to idealise the history of Judah, in the spirit of post-exilic Judaism. Based on the content of the book, Keil and Delitzsch (1976:12) argued that the general sketch apparently showed that the author had not the general history of Israel in view, from the time of David to the Exilic period. Rather, the Chronicler's only motivation was to sketch the history of David's reign and his successors, Solomon and the kings of Judah to the fall of Jerusalem. In an attempt to compare the history of Israel in Chronicles, with the representation of the history of Israel in those times in Samue and Kings, one can easily see that the Chronicler has omitted much of the history. 
Jonker (2013:136-137) observed that 1 Chronicles 21:1 shows an interesting departure from the source text in 2 Samuel 24:1, which he attributes to theological difficulty. The Chronicler omitted 2 Samuel 24:5-8a, which described the route that Joab and his commanders took when conducting the census. Instead, the Chronicler abbreviates the description in 1 Chronicles 21:4 and the direction of the route in 2 Samuel 24:2, which was 'from Dan to Beersheba', and he reverses from the south (Beersheba) to the north (Dan). This, according to Jonker, is not a merely ordinary abbreviation of the source text but a reflection of the Chronicler's Southern perspective. In other words, the Chronicler's background is rooted in the Southern tradition. By emphasising the Southern tradition, the Chronicler succeeded in emphasising the importance of the Jerusalem temple.

The Chronicler presented David's renewed petition to Yahweh in 1 Chronicles 21:17, as a heavily adapted form of the source text in 2 Samuel 24:17. In Jonker's view, David took responsibility for the wrongdoing of the census and, therefore, asked Yahweh to punish him and his house instead of the people. This action by David is interpreted by Jonker as a realisation that this incident has implications for Yahweh's eternal promise to his house. Akin to Jonker's interpretation, the Chronicler could be said to have alluded to the Davidic Covenant (Jonker 2013:138).

There is an allusion to what can be referred to as the significant Israelite tradition in verse 18 . There is a difference from the source text in 2 Samuel 24:18, in which case the Chronicler involved the angel of the Lord as a representative of Yahweh. In this account, the angel, instead of destroying the city, commanded Gad to tell David to go up and build an altar. The three elements of the Zionist tradition became prominent in this command by the angel, and they are the city (Jerusalem), the Yahwistic religion (represented by the altar) and the monarchy (represented by David). The concept of building an altar is also a strong reference to cultic practices, which are in the Chronicle's perspective centred at the Jerusalem temple (Jonker 2013:138).

A subtle difference can also be noticed in the actual transaction narrated in 21:21-25 and the source text of 2 Samuel 24:20-24. The huge price difference indicates that the Chronicler wanted to ensure that David's conduct would come across as being without any blemish. Also, the acquiring of the threshing floor that would become a cultic site had to reflect David's piety and reverence. Adapting to the changing tradition, the Chronicler's contemporary audience was made to receive confirmation of the legitimacy of their cultic site (Jonker 2013:139).

There is another allusion to Israelite tradition by the Chronicler to reflect his theological intentions. The Chronicler reworked the source text of 2 Samuel 24:25, in 1 Chronicles 21:26-27. Here the Lord answered David with fire from heaven on the altar of burnt offering. The Chronicler added the 'fire from heaven' to his source material. This addition by the Chronicler could be said to be an allusion to the Mosaic tradition and the Sinai tradition. In the two cases, the appearance of Yahweh was often accompanied by fire, for example, Moses at the burning bush and the revelation of the Torah at Sinai. Therefore, the Chronicler recounted the events this way to emphasise the importance of what was happening at the site of the Temple. David became in this process a Moses redivivus, and the Chronicler attempted to overwrite Moses with David. This overwriting entailed an overwriting of the Northern tradition with the Southern Tradition, an overwriting of Tabernacle tradition with Jerusalem temple tradition, an overwriting of the Sinai tradition with the Zion tradition and an overwriting of the exodus tradition with the monarchical tradition (Jonker 2013:139).

1 Chronicles 21:29-30 are without parallel in the source text. The Chronicler used this addition to achieve a contrast between the sanctuary that was at Gibeon and the newly established altar on the Jebusite threshing floor (Jonker 2013:140). I am also convinced that the Chronicler used this addition to drive home his complete dependence on the Zionist tradition. The tradition as narrated earlier has the three elements of the city (Jerusalem or Zion), the Yahwistic religion (the Temple) and the monarchy represented by David.

The book of 2 Samuel, which is one of the primary sources the Chronicler depended on, belongs to the literary unit of Torah (Campbell 1994:32-33). Campbell was commissioned to write an article for a symposium in honour of the German scholar Martin Noth (1902-1968) and to stay as close as possible to Noth's Deuteronomistic history. Campbell understands that the concept of a Pentateuch gives structure to the early traditions of Israel. He noted that Israel constituted a people brought out of Egypt into independence, set on the journey to a promised land. Israel's tradition gave the texts that narrate their journey a recognised unity as Torah, which generally belong to the Sinai tradition. At the significant events in history, the texts let leading personages perform in a speech, either extended or short, that glance 'forward and backward to interpret the course of events' (Campbell 1994:33). Campbell, agreeing with Noth, identified some of these passages to demonstrate the literal unity of the Deuteronomistic texts.

Examples of these passages are Joshua 1, 23; Judges 2:11-12; 1 Samuel 12:6; 1 Kings 8:14-16; and 2 Kings 17:7. These passages contain either speeches or summaries by Israeli leaders to demonstrate the continuation of their tradition history and the link between the books. Thus, they are recognised as a unit. According to Campbell, the structural divisions in the Deuteronomistic text are marked according to Noth, by Joshua 23:1; 1 Samuel 12 and 1 Kings 8:4. The unity of the Deuteronomistic text is very obvious, confirming the understanding of history as a self-contained unit. This unity is confirmed by Noth's recognition that the key date from Exodus to 1 Kings 6:1 spanned 480 years; a figure that is explicitly given in the Deuteronomistic history (cf. Campbell 1994:32-33).

Likewise, Braun's (1994:63) assertion about Noth's dealings with the character of Chronicler's work is that it stands 
out as an independent narration to enliven and develop the details of history. This, he supposed, is in contrast to the Deuteronomistic work that is a systematic presentation of history.

Furthermore, the Chronicler's speeches are inserted at opportune moments and, as Braun claims, this agrees with Noth's and von Rad's viewpoints, supposing that the speeches are implied like the Levitical sermon current in the Chronicler's day. Also, the Chronicler's prophets or seers appear as spokesmen for Judah, declaring the doctrine of retribution, an outlook that was conditioned by the conceptions of his day (Braun 1994:63).

Knoppers (2000) explained the concept of the Deuteronomistic history as a 'theoretical construct' and said:

Deuteronomistic History is a modern theoretical construct which holds that the books of Deuteronomy, Joshua, Judges, Samuel, and Kings constitute a single work, unified by a basic homogeneity in language, style, and content. The work covers much of Israel's history - from the time just before Israel entered the land (Deuteronomy) to the exiles of the Northern (2 Kings 17; 722b.c.e.) and Southern Kingdoms (2 Kings 25; 586 b.c.e.). That most scholars in the second half of the twentieth century have viewed the books of Deuteronomy through 2 Kings as essentially one corpus owes much to the influence of Martin Noth's classic study of the Deuteronomistic History, contained in his larger Überlieferungsgeschichtliche Studien According to Noth, the Deuteronomist incorporated the deuteronomic law into the beginning of his work, framing it with speeches by Moses. The Deuteronomist then added other sources, such as tales of conquest and settlement, prophetic narratives and speeches, official annals and records. The Deuteronomist organized these disparate materials, shaped them, and inserted his own retrospective and anticipatory comments (often in the mouths of major characters) at critical junctures in his history. (p. 1)

The Deuteronomistic history was not the compilation of an editor; rather, historical materials from highly varied traditions (some oral, whilst others may have been written) were brought together by an author and carefully arranged in a conceived plan (Campbell 1994:33).

The Exodus tradition was not mentioned in the narrative of 1 Chronicles 21. This narrative does not discuss the exodus from Egypt or the subsequent revelation at Mount Sinai (cf. Japhet 2009:296). Not only was the historical event omitted from the narrative but references to it have also been deleted in parallel texts. The exodus from Egypt appears only in the Deuteronomistic sections of the books of Samuel and Kings (Japhet 2009:297).

The Chronicler's ideology can be understood through the different traditions he emphasised. In 1 Chronicles 21, he emphasised the Zionist tradition, David (who is seen as the founder of the Jerusalem temple), the Jerusalem temple tradition, the Southern traditions and the concepts of temple rituals highlighted by an overemphasis on ritual practices. However, he omitted or underemphasised the following traditions: Moses, the Exodus, the Sinai tradition, the Northern traditions, the Northern Kings (referring to the Northern Traditions), as well as the worship places associated with the Northern tribes, like Shechem and Bet-el.

\section{The different traditions that are emphasised and underemphasised or wholly ignored in 1 Chronicles 21}

Many traditions were emphasised by the Chronicler in 1 Chronicles 21: The Temple, Zion and Southern traditions. The Chronicler underemphasised the patriarchal, Northern, Mosaic and Sinai traditions. However, the Southern and the three elements of the Zionist tradition, the site, the Yahwistic religion and the monarchy were his main emphasis.

The Chronicler's ideology can be understood through the different traditions he emphasised. He emphasised the Zionist tradition, David (who is seen as the founder of the Jerusalem temple), the Jerusalem temple tradition, the Southern traditions and the concepts of temple rituals. However, he omitted or underemphasised the following traditions: The patriarchal tradition (portraying Yahweh as the God of Abraham, Isaac and Jacob), the Exodus tradition (Moses), the Sinai tradition (Moses), the Northern traditions, the Northern Kings (referring to the Northern Traditions).

Therefore, what the Chronicler sought to achieve in his writing was to encourage the restoring community, his post-exilic audience, to find their identity in a multicultural environment, as God's people and heirs of the promises of David and to legitimise the Temple as the only place of true Yahweh-worship, safeguarding the position of the temple elite.

The redaction activity found in the book of Chronicles was motivated by the Chronicler's theological and ideological purposes. The Chronicler collected, arranged, edited and modified the traditional material and turned the composition into new material that is ideologically loaded and focused on a specific theological viewpoint. The Chronicler's major sources amongst the biblical works are the historical compositions. He emphasised some of them in full and others in a reworked form. He did not take extensive literary excerpts from the prophetic books. He underemphasised some psalms. The Chronicler's style is a display of a skilful balance of omission, additions and changes that transform his final work into narratives that are different from the sources and sometimes conflicting.

The Chronicler appeared to have surveyed the books of Samuel, Kings, Joshua, Genesis and other parts of Pentateuch as source material for his writing, but his picture of Israel's history is emphatically different from that of the source material. His work is a record of the only legitimate kingdom of Judah, instead of being a synchronistic history of the two kingdoms. He used exclusive language to include the 
Southern kingdom and exclude the Northern kingdom. He only includes in his record the Northern kingdom in passages where the relationship between the two kingdoms is recorded and ultimately judges these relationships negatively. At the same time, he supplements his records with extra-biblical traditions. The Chronicler also borrowed from Ezra-Nehemiah, the edict of Cyrus and the list of the inhabitants of Jerusalem. Yet, these stories serve a different purpose in Chronicles, showing his view to be critically divergent from EzraNehemiah concerning the history of Israel. The Chronicler's theology and ideology predisposed his selection, omission and treatment of the material he borrowed from older histories, prophetic writings and perhaps other writings.

The Chronicler changed the direction of the census taking to read from Beersheba to Dan (from South to North), instead of from Dan to Beersheba (from North to South). This is an overwriting of the Northern tradition with the Southern tradition.

The answer to David's prayer was met with fire from heaven, according to the Chronicler. This is an addition to the source text. It is suggested to be an allusion by the Chronicler to the Mosaic tradition (Moses met by fire at the burning bush) and the Sinai tradition (fire at Mount Sinai during the receiving of the Law). The Chronicler underemphasised both the Mosaic and the Sinai traditions; therefore, this could be termed as overwriting of these traditions by the Davidic tradition.

Finally, the Chronicler added the last portion of the text in 1 Chronicles 21:28-30, which is without parallel in 2 Samuel 24 . These verses try to explain the reason why David could not go to the altar at Gibeon. The Chronicler may have used this to achieve a contrast between the sanctuary that was at Gibeon and the newly established altar at the Jebusite threshing floor. This links with the notion that the Chronicler replaced the Tabernacle tradition with the Temple tradition.

\section{A reference to why Satan was brought into the story and his character}

There is redaction activity in 1 Chronicles 21 , relative to the supposed source narrative in 2 Samuel 24. 1 Chronicles 21:1 state that it was Satan who stood up against Israel and moved David to number the Israelites, whilst 2 Samuel 24:1, states that it was the anger of the Lord that was aroused against Israel and that he moved David to number his people. Some scholars believe that the insertion of the figure Satan in this verse is an attempt to extract the evil from Yahweh.

The Chronicler detached the story from its former context in two ways: firstly, he omitted the anger of God, and secondly, the incitement to number the Israelites was not attributed to God, but another agent. All English translations follow a long exegetical tradition, according to which Satan serves as a proper noun and read Satan.
The general attitude of Chronicles, however, is that evil, as well as good, originates from God. Given the different considerations, theological as well as linguistic, the conclusion is that the figure of Satan still serves as a common name and refers to an adversary.

It is striking how few are revealed about Satan and the fact that he is not mentioned in any other chapters from 1 and 2 Chronicles. He is a flat character in the narrative. The Chronicler actually created an empty image of Satan, which links with his belief that God is almighty and that no other creature or symbol can be mightier than God. He is only a pawn in the Chronicler's narrative. His purpose was to promote the Chronicler's theology.

\section{Remarks regarding the possible contemporary relevance of this text}

It became clear that the author(s) of Chronicles replaced certain traditions with the monarchical tradition to emphasise the Jerusalem temple, which has both a theological and ideological motive behind it.

The Jerusalem Temple represented the Chronicler's theology and his image of God - which was that Yahweh is only to be worshipped in the Jerusalem Temple and that he has chosen the site as the place for worship and dwelling. The Temple also represented the ideology of the Chronicler, because by emphasising the Temple, he succeeded in securing the temple elite's position as the ruling officials.

In finding out that this text is theologically driven and ideologically loaded, the question arises: What impact does it have on our understanding of this text, and can it still be relevant today?

It seems that the real question here is hermeneutical. In addressing this issue, a few key concepts relating to a person's hermeneutical options should be considered. ${ }^{3}$

The Bible, and especially the Old Testament, does not contain a central theme or one theology. This makes it essential that each text should be understood and read within its unique historical framework. The tradition criticism has revealed the different theologies and ideologies that were in existence in ancient Israel. The notion of tradition history can be linked with the hermeneutical options one should consider towards making a contemporary interpretation. The diversity of the Old Testament reflects not only the reality of life as expressed by people in different times and contexts but also their testimony of the relationship between God and humans. The diversity of the Old Testament is a mirror image of the society in which we live. The Old Testament texts function side by side and not opposite to each other. It requires flexibility in thinking to interpret texts as having

3.Most of these concepts are described in detail by Geyser-Fouche $(2016,2017)$ and will only be shortly mentioned. 
different purposes and therefore being relevant in different contexts.

In the Old Testament hermeneutics, the reader should be brave enough to throw off cultural ties and focus only on what matters. It requires reading the controversy and polemic in the text and not being influenced by it. The controversy and polemics in the text are directed against a particular text or culture at a particular time and can therefore not be taken as law or gospel. That is why it is important to read and understand a text within context. What matters in any text is the relationship between God and humans, and this is what the interpreter should translate into today's context, not the culture or the controversy.

In an attempt to create a personal interpretation of how the ideologically motivated text can still be relevant for us today, the following options can be taken into consideration.

Israel was a confused nation seeking identity after the exile. An author like the Chronicler wanted to give them direction by telling them that they can find identity in their relationship with God. Although he has used the ideologically loaded symbol of the Temple, it can be translated into today's context to a relationship with God. This entails that people who are feeling confused about their circumstances and identity, today, can find certainty in their relationship with God, regardless of how and where they worship. The flat character of Satan links with the Chronicler's belief that God is almighty and that no other creature or symbol can be mightier than God. The notion that the whole of Israel is only the persons worshipping in Jerusalem might seem like the exclusion of persons but can be linked to how the Chronicler tried to give security to a confused nation and can also be translated in our contexts to our relationship with God, regardless of where, how and with whom we worship.

Considering the varying principles garnered from the study of a text, we should not focus on the culture or the controversy, but rather on the relationship between God and humans.

\section{Acknowledgements Competing interests}

The authors have declared that no competing interest exists.

\section{Authors' contributions}

The article is an adaptation of a part of the $\mathrm{PhD}$ thesis of EB, prepared under the supervision of ABGF.

\section{Ethical considerations}

This article followed all ethical standards for research without direct contact with human or animal subjects.

\section{Funding information}

This research received no specific grant from any funding agency in the public, commercial, or not-for-profit sectors.

\section{Data availability}

Data sharing is not applicable to this article as no new data were created or analysed in this study.

\section{Disclaimer}

The views and opinions expressed in this article are those of the authors and do not necessarily reflect the official policy or position of any affiliated agency of the authors.

\section{References}

Boda, M. \& McConville, J., 2012, Dictionary of the Old Testament Prophets, InterVarsity Press, Downers Grove, IL.

Braun, R., 1994, 'Martin Noth and the Chronicler's history', in S. Mckenzie \& M Graham (eds.), The history of Israel's traditions: The heritage of Martin Noth, Journal for the Study of the Old Testament Supplement Series 182, pp. 63-80, Sheffield Academic Press, Sheffield.

Breytenbach, A.P.B., 1995, 'Jesus Christus in die Ou Testament', Die Hervormer 88(18), 708-709.

Brueggemann, W., 2008, Old Testament theology. An introduction, Abingdon Press, Nashville, TN.

Brueggemann, W., 2013, Truth speaks to power. The countercultural nature of Scripture, Westminster John Knox Press, Louisville, KY.

Campbell, A., 1994, 'Martin Noth and the Deuteronomistic history', in S. Mckenzie \& M. Graham (eds.), The history of Israel's traditions: The heritage of Martin Noth, Journal for the Study of the Old Testament Supplement Series 182, pp. 31-62, Sheffield Academic Press, Sheffield.

Glassie, H., 1995, 'Tradition', Journal of American Folklore 108(430), 395-419. https:// doi.org/10.2307/541653

Geyser-Fouche, A., 2017, 'Die kerk vanaf die Ou Testament en die Nuwe Testament tot vandag I: "Voortsetting, vervanging of transformasie?"', HTS Teologiese Studies/ Theological Studies 73(1), a4570. https://doi.org/10.4102/hts.v73i1.4570

Geyser-Fouche, A.B., 2016, 'Exclusive language: The tool to empower and create identity', Verbum et Ecclesia 37(1), 1-9. https://doi.org/10.4102/ve.v37i1.1495

Grisanti, M., 1999, 'Davidic Covenant', The Master's Seminary Journal 10(2), 233-250.

Holladay, C. \& Hayes, J., 1982, Biblical Exegesis: A beginner's handbook, John Knox Press, Atlanta, GA.

Japhet, S., 1968, 'The supposed common authorship of Chronicles and Ezra-Nehemiah investigated anew', Vetus Testamentum 18(3), 330-371. https://doi. org/10.2307/1516644

Japhet, S., 2009, The ideology of the book of Chronicles and its place in Biblical thought, Eisenbrauns, Warsaw, IN.

Jonker, L., 2013, 1 \& 2 Chronicles, understanding the Bible commentary series, Baker Books, Bellingham, WA.

Keil, C. \& Delitzsch, F., 1976, Commentary on the Old Testament, Wm. B. Eerdmans Publishing Company, Grand Rapids, MI.

Knoppers, G.N, 2000, 'Introduction' in G.N. Knoppers \& J. MacConville (eds.) Reconsidering Israel and Judah: Recent studies on the Deuteronomistic history, pp. 1-10, Eisenbrauns, Winona Lake, IN.

Knoppers, G.N., 2004, 1 Chronicles 10-29. A new translation with introduction and commentary, Yale, The Anchor Yale Bible.

Nahkola, A., 2001, Double narratives in the Old Testament: The foundations of method in Biblical Criticism, Walter de Gruyter, New York, NY.

Smith, G., 2010, Ezra-Nehemiah Esther, Tyndale Cornerstone Commentary, Tyndale House Publishers Inc., Carol Stream, IL. 